\title{
PRIVATE WEALTH MANAGEMENT: THE CASE OF THE REPUBLIC OF SERBIA
}

\begin{abstract}
Today's challenges of wealth management can be noticed by its dynamic competition, fees, stricter regulation and ever-growing needs of clients. These challenges affect responses of interest groups, which consequently promotes critical trends of consumer needs, new technology, changes in advisory models and safety. Clients'growing insight into financial planning is only demanding greater digital possibilities and better advisory options. In regard to the rapid evolution of technology, companies are forced to quickly improve their respective offers for clients. For a very long time, wealth management was only possible in well-developed countries, and their citizens were in a position to be provided with advice regarding wealth management. This branch has lesser significance in countries in transition, since such countries are less wealthy. However, as a result of globalization and the huge growth of gross national product this situation is slowly improving, in spite of financial destabilization and slower economic development. Amidst changes in the allocation of wealth and relative significance of different markets, parameters for the wealth market are changing. The topic of this essay will elaborate on private wealth management in our country. Also, wealth management models will be touched upon, which ones were applied in the past, like the ones that are being used today. Possible improvements of the same will be discussed as well. In our country, the term management of private wealth is still largely unknown. Considering the place that Serbia takes, it is necessary to take measures to improve the indicators, with the aim of improving its position on this list for managers of private equity management. Theoretical and molecular methods have been used in this paper, and the purpose of this work is to present the management of wealth in general, with particular reference to the Republic of Serbia.
\end{abstract}

Key words: private wealth, management, investment, models, planning, Serbia.

JEL classification: 621,016

\section{УПРАВЉАЊЕ ПРИВАТНИМ БОГАТСТВОМ: СЛУЧАЈ РЕПУБЛИКЕ СРБИЈЕ}

\begin{abstract}
Апстракт
У интензивној конкуренцији, компресији, накнадама, строжој регулативи и растућим потребама клијената огледају се изазови индустрије управљања богатством. Ови изазови утичу на одговоре интересних индустријских група, што за последицу има критичне трендове у потрошачким потребама, нове технологије, промене саветодавних модела, сигурности и координисаности. Особеност клијената управљана богатством јесте све већа прони-
\end{abstract}

${ }^{1}$ monia-ch.milutinovic@db.com 
иљьивост у вези са финансијским планирањем и имају потребу за већим дигиталним могућностима и бољим саветодавним опцијама. С обзиром на брзи технолошки развој, од компанија се захтева агилност са ицием унапређена услуга које пружају клијентима. Веома дуго је услуга управљања имовином била омогућена само држављанима развијених држава, којима је било омогућено да добијају савете у вези са управљањем богатством. С обзиром да имају мање богатства, у државама у транзичији ова индустријска грана има мањи значај. Међутим, овакво стање се постепено мења као последиияа глобализације и великог раста бруто друштвеног производа, упркос финансијској дестабилизацији и успореног развоја економија у овим државама. Услед промена у расподели богатства и релативној важности различитих тржишта долази до промена параметара тржишта богатства. Предмет овог рада представља приватно управљање богатством у нашој држави. Такође, приказаћемо и моделе управљања богатством какви су били некада, а какви се примењују данас, а бавићемо се и могућностима побољиања ових модела. У нашој земљи термин управљање приватним богатством још увек је у великој мери непознат. С обзиром на место које Србија заузима, потребно је предузимање мера како би се показатељи побољиали, са ииљем унапређењ а свог положаја на овој листи за менаиере управљања богатством приватног капитала. У раду је коришћена теоријска и исраживачка метода, а сврха рада је приказ управљања богатством уопште, са посебним освртом на Републику Србију.

Кључне речи: приватно богатство, управљање, улагање, модели, планирање, Србија.

\section{Introduction}

Private wealth management represents an investment advisory practice, which is based on financial planning, portfolio managing and other aggregate financial services that are provided to individuals, which differs from the services that corporations or investment groups are provided with. From the client's perspective, private wealth management is a practice which resolves or improves their financial situation, and which also enable their short-term and long-term goals, with some assistance by financial advisors. From the financial advisor's perspective, private wealth management is a practice which serves for delivering financial products and services to wealthy clients, which propels them to reach their pre-set financial goals.

Efficient wealth management demands a certain amount of time, effort and essential knowledge, which many individuals lack. And as they are incompetent to act on it on their own, they ask for advice wealth managers who are experts in private financial management, and prolific in dealing with HNWI (High-net-worth individual). In a holistic approach to investment management the approach to HNWI can be noticed too. And in a much bigger extent in comparison with other financial advisors. Income tax, real estate management, investment management and the rest of legal jobs create problems for HNWI, and they demand greater attention and specific expertise with traditional qualified investment advisors.

The majority of private companies that deals with wealth management represent smaller groups in the network of bigger financial institutions whose focus is upon providing personalized services to their clients. The primary goal of these institutions is 
the management and expansion of their client's real estate, which is to be left to future generations. In these groups, there are different advisors who can respectively advise people about cash, fixed income, stocks and alternative means of investment. These experts can create a list of ways in which improvement can be made without exceeding investor's tolerance.

Private firms which are in real estate management business make their profit based on fees. These firms take percentual cuts from their clients' managed real estate. According to HNWI, a financial advisor's job, who also works on fees, creates a smaller clash of interests unlike traditional advisors, who work on commission.

\section{Private wealth management today and before}

One of the two companies, Goldman Sachs or Morgan Stanley is thought to be responsible for the creation of phrase "wealth management" during the 1930s with a desire to distinguish wealthy clients from expansive markets. In that period wealth management was just a niche service, as the banks focused on accounts with average value from 10 to 20 million dollars. In the late 1980s, this phrase gained its popularity as banks and stockbrokers gained much more knowledge. Under their guidance, many seminars were organized and events at which sponsor firms used to showcase their traits and services. The wealth management industry was shaken by the big recession at the beginning of this century (Beaverstock, et.al., 2013). Then it was clear that individuals had to possess sufficient knowledge about wealth management and those same individuals had to have a better rapport with the managers of their wealth. Very quickly the ways how wealth is managed have changed, very much thanks to digital resurgence. ${ }^{2}$

In the last decade, a Copernicus-like shift has occurred, as the number of available data clients could use have expanded greatly. That way they not only had more data they could work with, but their power also rose. So, the wealth management industry has changed fundamentally as a result of more available data, technological advances, changed expectations, client's desires, demographic trends, and regulatory changes. These changes work in consumer's benefit (Jennigs, et.al, 2011). At the same time, the wealth management industry has been improving, which as a result can offer their clients more thorough consultation and suggestions. As a consequence of that, instead of more thorough suggestions, relationships based on transactions have been introduced, such as investment groups or annuity. Here's financial planning as an example (Ang, 2010).

The first phase of the process is a formal meeting between the client and manager for relations and planning, which often uses a very complex computer tool for planning. After the meeting, there is allotted time that is spent on planning and creating a thorough strategy for the client, which can be in the form of a book. Sometimes this can oversaturate a client with information. Nowadays, as interactive tools are easily accessible, the inclusion of the client in the process is much more possible (Ljumović, Marinković, 2013). So, there is a possibility of picking in which phase a client will be included. Also, there is a possibility of meeting with the planners, who can provide them will all details in regards to their wishes and needs.

\footnotetext{
${ }^{2}$ https://www.investopedia.com/terms/w/wealthmanagement.asp: 01.03.2019.
} 
Figure 1. Private Wealth Management Concept

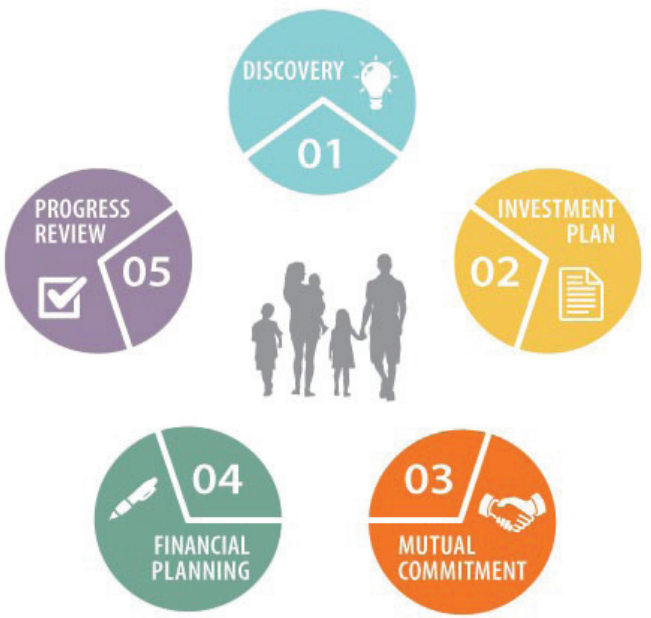

Source: http://www.thehockgroup.com/private-wealth-management.7.htm

This segment of the global market has gained its attractiveness because of its size, and possible growth. In today's market, the amount of money for net investments exceeds 55.000 billions of dollars. Global wealth model states how by 2021 the sum of investment will be around 69,607 billions of dollars. So, it will be at least one fourth bigger than today's, meaning the annual growth rate will be $4.7 \%$. The anticipation and exploitation of this market potential and growth is a must. ${ }^{3}$

Figure 2. Total net investments shown in trillions of dollars - 2016 with total growth up to 2021.

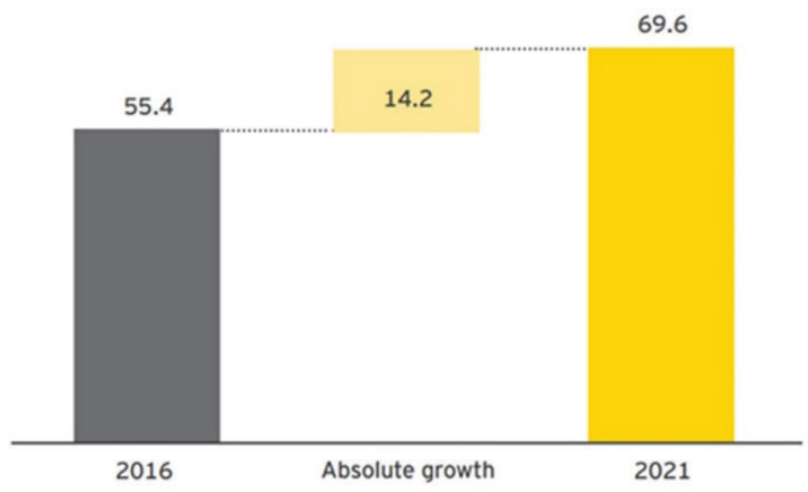

Source: file:///C:/Users/Milan/Downloads/ey-wealth-management-outlook-2018\%20 Version\%20Lux.pdf

\footnotetext{
${ }^{3}$ https://www.ey.com/Publication/vwLUAssets/ey-wealth-management-outlook-2018/\$file/eywealth-management-outlook-2018.pdf: 11.03.2019.
} 
The basic difference between private banking and wealth management is represented by the fact that private banking doesn't have to mean investment always. Private banks' experts can give their clients advice on possible investments, but not all banks will participate in investment for their clients (Amenc et.all, 2009). Users of private banking services open deposit accounts of any kind. In order to improve their financial situation and realize their high income, private wealth managers with their financial advisors provide their clients with advice. In the broadest sense, there is a possibility of private banking expansion with the goal to manage the real estate, whereas there aren't possibilities to provide the services of private banking from companies who are in wealth management.

\section{Wealth management leaders in the world}

In the basis of private banking growth, there is a bigger income on the classes of real estate in relation to the average growth of gross domestic product (GDP) (Brunel, 2006a). Accumulation of means depends on four mechanisms: approach to market, expertise, negotiating skills and inclusion of constituents.

Table 1. The largest private banks and wealth managers in the world of 2018

\begin{tabular}{|c|l|c|}
\hline $\begin{array}{c}\text { 2018 } \\
\text { Rank }\end{array}$ & \multicolumn{1}{|c|}{ Company } & Assets Under Management (AUM) \\
\hline 1 & UBS & $\$ 2,403$ billion \\
\hline 2 & Bank of America Merrill Lynch & $\$ 1,080$ billion \\
\hline 3 & Morgan Stanley & $\$ 1,045$ billion \\
\hline 4 & Credit Suisse & \$526 billion \\
\hline 5 & J.P.Morgan Private Bank & $\$ 460$ billion \\
\hline 6 & Citi Private Bank & $\$ 436.7$ billion \\
\hline 7 & BNP Paribas & $\$ 394.3$ billion \\
\hline 8 & Goldman Sachs & $\$ 388.3$ billion \\
\hline 9 & Julius Baer & $\$ 292.8$ billion \\
\hline 10 & China Merchants Bank & $\$ 289.8$ billion \\
\hline 11 & Northern Trust & $\$ 228$ billion \\
\hline 12 & HSBC Private Bank & $\$ 256.8$ billion \\
\hline 13 & Deutsche Bank Wealth Management & $\$ 248$ billion \\
\hline 14 & Wells Fargo & $\$ 206$ billion \\
\hline 15 & The Industrial and Commercial Bank of & \\
\hline
\end{tabular}

Source:https://www.businessinsider.com/the-15-biggest-wealth-managers-in-the-world2018-6\#4-credit-suisse-792-billion-12

As an example, we can take family offices, which thanks to the expansion of their direct and part investive affiliates demand the best alternative possibilities for investment. Competence regarding nurture and development of wealth are transferred from one generation to another, and therefore they can nurture and improve long-term relationships with banks and wealth managers. With a high number of investments and private wealth the conditions for unusual and complex investment are set, and a great position of power is established in negotiations. Thanks to diverse connections with 
business, politics, and society, very strong connection are formed, which itself have great significance for molding conditions of political and market economic entity which is in check with specific tendencies for wealth preservation. ${ }^{4}$

The retirement of private wealth manager is necessary in order to analyze one's situation thoroughly. A manager who defines his work by his competence, that is ever growing, will be in pole position, as opposed to those who don't improve their abilities.

Figure 3. Factors that influence the management of private wealth

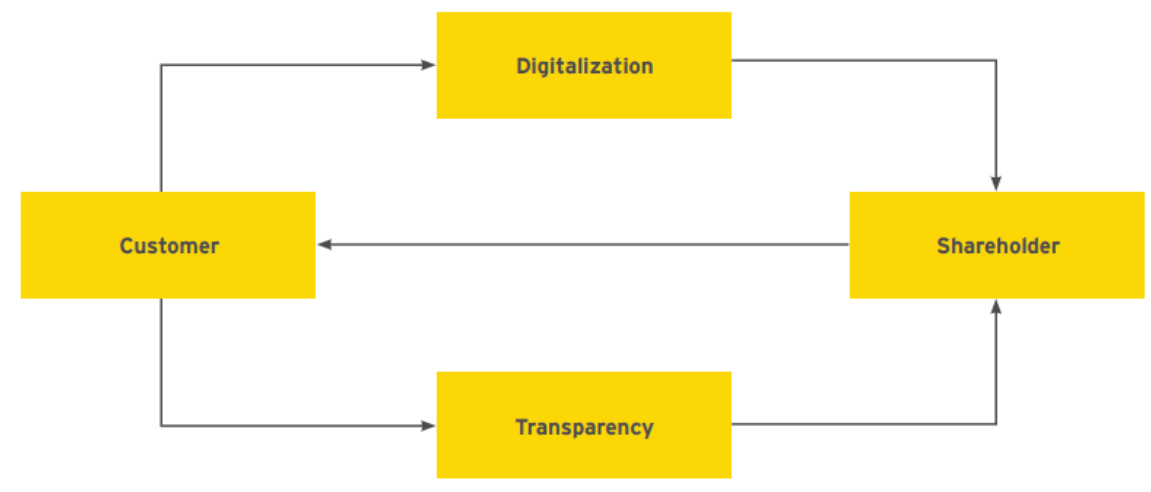

Source: http://www.thehockgroup.com/private-wealth-management.7.htm

It's a must for top managers to work on redefining their wealth management strategies. Diagnostics, vision, and differentiation are just some of the processes managers go through. Also, they must ask themselves questions about which markets they want to engage in, how they want to function, how their offers are more valuable than the offers of other managers, and which traits they need (Brunel, 2006a). A top manager's strategy should be based on adequate analysis of the current situation, and the grasp of changes in the industry is also very important. Based on this strategy their future activity and orientation are defined. Acceleration of organic growth based on the revision of the current market position and the value of offers on land and foreign markets should serve for the first step in redefining wealth management strategies. The analysis of current market positioning in comparison to the competition and decision making about the desired market position should be the beginning of a revised strategy (Adam, 2009).

\section{Private wealth management in Serbia}

In our country, the term private wealth management is still widely unknown. In Serbia there are many wealthy people, given the population of the country is decreasing, as the younger individuals are migrating in search of a better life. The term 'private banking' is much more present in our country, and it's much more known than 'private wealth management'.

Providing services in the field of banking, investment and other services to wealthy individuals represent a field of private banking operations, which is actually

\footnotetext{
${ }^{4}$ https://worldwealthreport.com/resources/world-wealth-report-2018/: 12.03.2019.
} 
a separate domain of banking. Very often terms 'wealth management' and 'private banking' are mixed up, which are in most cases defined as a service of client's financial active management, that is long-term with the goal of real estate accretion. The clientele consists of wealthy individuals, who are enabled easy access to personalized service (Milenković, 2015). Basically, the real difference between private banking and wealth management are different kinds of institutions that can deal with certain activities. The services provided by private banking based on more specific adjustment can be given by banks only, whereas services of wealth management can be given by other institutions of financial characters, such as investment groups, etc.

The second Belgrade Wealth Forum had a major role in the process of private wealth management development. At this event, there were more than 150 participants from 20 different countries. For the first time were Serbian residential programs, aligned with current legislation, presented to those in attendance (Ljumovic, Marinkovic, 2013). Andorre, which is an exclusive program intended for a limited number of wealthy individuals with impeccable biography was also presented at the event.

Future development of banks in Serbia is reflected on the digital platform, based on which a complete banking system will be changed, with help from their intermediaries, which are management companies, and institutions for electronic money. If a big investment phase were to emerge in Serbia, a big part of it would be a project that would be based on launching the program of Serbian nationality. ${ }^{5}$

Automatic exchange of information among countries, implementation of remaining conventions of OECD, with which transparency in business would be achieved and the decrease of possibility for tax optimization and privacy protection will become a topic that will collect greater attention at international level, but in Serbia too, in order to improve private wealth management.

UniCredit Bank ${ }^{6}$ and Hypo Alpe Adria Bank (now Addiko Bank) ${ }^{7}$ were the first banks that started offering private banking services, the services that are closest to the form of private wealth management in Serbia. Raiffeisen, Komercijalna bank and Eurobank were the first to offer VIP banking service, which is considered the precursor of the creation of a private banking sector. In short, its first branch of UniCredit Bank opened at the beginning of 2008. The barrier for entry into the category for this type of service is 200,000 euros (worldwide this limit is much higher), which are deposited for investments, while the amount of monthly income should be higher than 5,000 euros.

This exclusive service provides clients with services such as asset management, maintenance, and growth of property, investment banking services, brokerage services, and real estate consulting. Potential clients on the market of our country are successful people, such as managers, athletes, media personalities, former shareholders of companies, that is, people who do not have time to care for their private money due to business obligations and therefore need private bankers. It is essential that property managers point to important changes in the financial market in order to consider risks with their clients. The situation in which a private banker is simultaneously an investment advisor is very desirable.

\subsection{Private Wealth Management in the region and investment models}

When deciding on placement of assets, wealth management managers are guided by the principle that relates to the necessity of capital demand and conditions in order to maximize

\footnotetext{
${ }^{5}$ https://www.knightfrank.com: 18.03.2019.

${ }^{6}$ https://www.unicreditbank.rs: 19.03.2019.

${ }^{7}$ https://www.addiko.rs: 19.03.2019.
} 
yields on the assets that are placed (Jääskeläinen, Maula, \& Murray, 2007). In the neighboring countries, the first condition was met, given the higher demand for capital in relation to its offer. Regarding the other conditions, managers find conditions for realizing their interest in market growth opportunities that are in the process of ascent. However, in such cases, there is great uncertainty and risk, but due to the reforms implemented in these countries and the harmonization of legislation with EU regulations, the risk factor is considerably lower.

The globalization of capital markets (both risky and private) is contributing to the harmonization of business conditions and risk reduction in countries, in addition to the reform process. Owing to this situation, the market is expanding, and consequently by reducing uncertainties and risks, which were an indispensable challenge for managers in the markets of the countries that are in the process of development (Schöfer, Leitinger, 2002). In order to assess the region of Central and Eastern Europe, it is necessary to approach the analysis of the attractiveness and position of individual countries in these regions (Groh et al., 2010). The contribution of this analysis is reflected in the perspective of Serbia's position in the region and the discovery of the leading countries when it comes to attractiveness for investment. ${ }^{8}$

The blue fields in the Table 1 view are countries that rank below the regional average. Given the ranking of the attractiveness index that makes the rank of the attractiveness of the selected indicators - so that the position of the state is more favorable is the lower value. A group of countries that, according to macroeconomic indicators of attractiveness below the median values in the region, consisting of Bosnia and Herzegovina, Montenegro, Croatia, Latvia, Macedonia, Moldova, Serbia, and Ukraine. Ranking of countries according to the criteria of attractiveness based on the indicator looks like this: Poland (1), Czech Republic (2), Hungary (3), Slovakia (4), Slovenia (5), Lithuania (6), Estonia (7), Bulgaria), Romania (9), Croatia (10), Latvia (11), Ukraine (12), Serbia (13), Bosnia and Herzegovina (14), Macedonia (15), Montenegro (16) and Moldova (17).

Table 2. The tax attractiveness index of the CEE countries in the period from 2007 to 2014.

\begin{tabular}{|l|c|c|c|c|c|c|c|c|c|c|}
\hline CEE countries & 2007 & 2008 & 2009 & 2010 & 2011 & 2012 & 2013 & 2014 & Mean & Rang \\
\hline $\begin{array}{l}\text { Bosnia and } \\
\text { Herzegovina }\end{array}$ & 77 & 71 & 79 & 73 & 76 & 72 & 73 & 75 & 74,5 & 14 \\
\hline Bulgaria & 50 & 55 & 55 & 53 & 56 & 54 & 53 & 56 & 54 & 8 \\
\hline Czech Republic & 34 & 37 & 35 & 34 & 34 & 33 & 35 & 37 & 34,87 & 2 \\
\hline Montenegro & 75 & 76 & 68 & 70 & 81 & 79 & 86 & 84 & 77,37 & 16 \\
\hline Estonia & 41 & 36 & 52 & 59 & 55 & 50 & 51 & 51 & 49,37 & 7 \\
\hline Croatia & 55 & 59 & 60 & 61 & 64 & 65 & 65 & 64 & 61,62 & 10 \\
\hline Latvia & 56 & 57 & 73 & 81 & 71 & 63 & 60 & 55 & 64,5 & 11 \\
\hline Lithuania & 46 & 43 & 53 & 65 & 51 & 44 & 43 & 43 & 48,5 & 6 \\
\hline Hungary & 43 & 48 & 38 & 39 & 38 & 41 & 42 & 45 & 41,75 & 3 \\
\hline Macedonia & 76 & 79 & 74 & 72 & 78 & 81 & 80 & 78 & 77,25 & 15 \\
\hline Moldova & 71 & 93 & 98 & 102 & 101 & 95 & 98 & 96 & 94,25 & 17 \\
\hline Poland & 35 & 34 & 33 & 29 & 29 & 28 & 28 & 29 & 30,62 & 1 \\
\hline Romania & 47 & 49 & 48 & 54 & 62 & 64 & 62 & 52 & 54,75 & 9 \\
\hline Slovakia & 48 & 47 & 45 & 42 & 45 & 45 & 44 & 48 & 45,5 & 4 \\
\hline Slovenia & 45 & 45 & 39 & 46 & 48 & 47 & 45 & 50 & 45,62 & 5 \\
\hline Serbia & 72 & 70 & 61 & 66 & 73 & 74 & 82 & 79 & 72,12 & 13 \\
\hline Ukraine & 67 & 66 & 72 & 82 & 77 & 71 & 69 & 63 & 70,87 & 12 \\
\hline
\end{tabular}

Source: Risk and Private Capital in the Countries of Central and Eastern Europe

${ }^{8}$ Invest Europe. (2016). Central and Eastern European Private Equity Statistics 2015. 
We can conclude, given the place in which Serbia is, that it is necessary to take measures in order to improve the indicators, with the aim of improving its position on this list for managers of the management of wealth of private capital (Pistor et.al., 2004). From a single point of view, Serbia's position on the list of attractiveness shows that during 2009, Serbia improved its ranking, but as a consequence of the major global economic crisis, the trend rate dropped, which reached its minimum level in 2013, followed by improvement of the position.

\subsection{Wealth structure in Serbia}

In Serbia there is certainly room for managing rich clients' assets. In a way, this has already started in our country through major universal banks (Milenković, 2015). With all the difficulties that hit Serbia in the 1990s, in the conditions of sanctions, in the wartime environment, crisis and poverty, this period also made the first wealthy Serbian people. According to some, the calculations before the economic crisis shook the Serbian economy, only a dozen of the largest businessmen had wealth of billions of euros. Thus, during the crisis in 2009 , the wealth of 10 people was equal to 30 percent of Serbia's GDP, or almost 10 billion euros.

If you look at Chart 1. you can see that the number of millionaires in Serbia is growing. The total number of millionaires in Serbia in 2005 was 1,300, while in 2015 this number was increased to 2400 . According to some research and forecasts, the number of millionaires in Serbia could increase to 3,500 in 2025, meaning each person of those 3500 would have wealth of at least one million.

\section{Graph 1. Total number of millionaires}

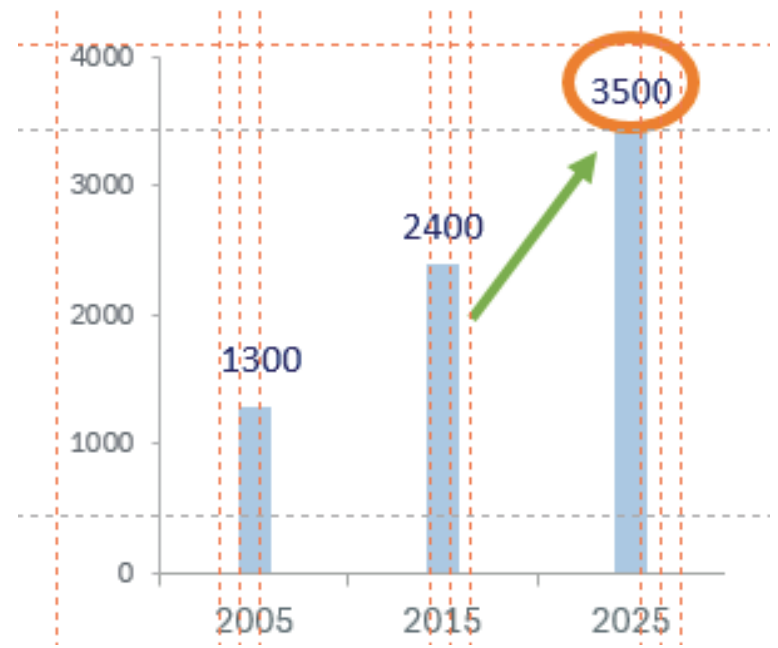

Source: The Wealth Report 2016 (Knight Frank), p. 54.

Nowadays, there is a slightly different structure of millionaires in Serbia. We are looking at millionaires who have at least ten or even more millions of euros in their accounts. In 2005, 60 people in Serbia have been registered with at least 10 million dollars or more in their account. It is interesting that the number of millionaires in 2014 and 2015 did not change. 
It has risen in comparison to 2005, but it has not changed, and there are 110 millionaires with 10 or more million dollars. The forecasts predict that in 2025 in Serbia there should be no less than 160 people with at least 10 and even more million dollars in their account.

Graph 2. Number of millionaires with 10 and more million

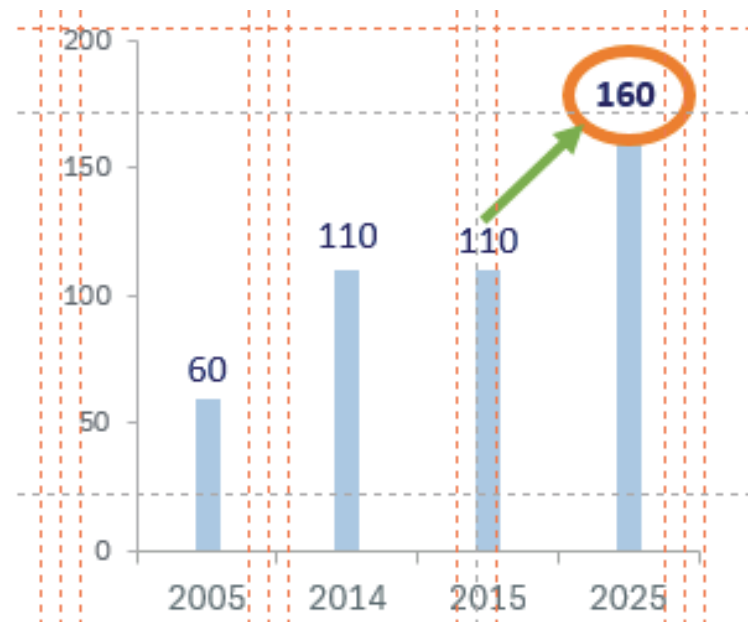

Source: The Wealth Report 2016 (Knight Frank), p. 54.

Graph 3 shows the number of millionaires in Serbia with 30 and more million. And here growth has been recorded during the span of 10 years. In 2005, 21 millionaires with 30 and more million dollars in their accounts were registered, while in 2015 this number rose to 38 million. The forecasts are such that in 2025 , Serbia should have 55 millionaires with 30 or more million dollars in their account.

Graph 3. Number of millionaires with 30 and more million

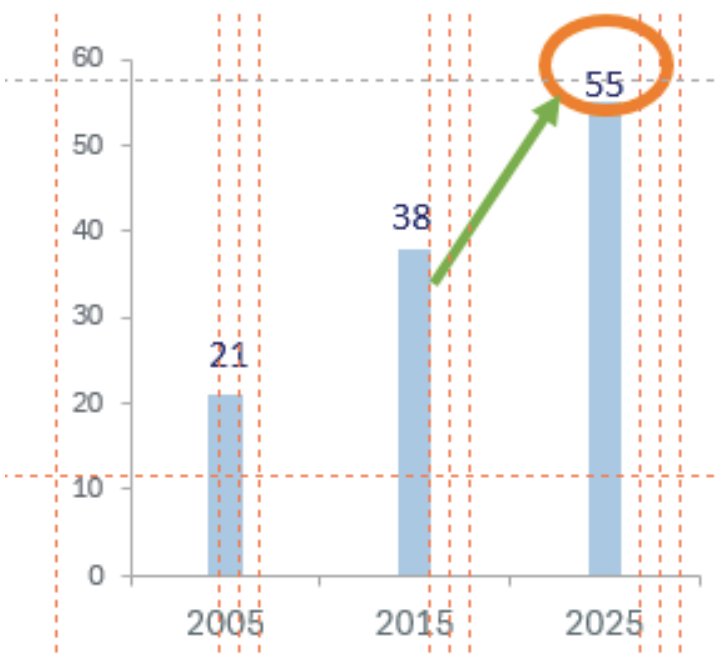

Source: The Wealth Report 2016 (Knight Frank), p. 55. 
Finally, we take a look at the richest people in Serbia, or people with 100 or more million in their account. In 2005, two people with this kind of bank balance were registered, while this number doubled in 2014 and remained the same in 2015. It is projected to grow in the next 10 years, meaning Serbia will have 6 millionaires with 100 and more million in its account in the year 2025.

\section{Graph 4. Number of millionaires with 100 and more million}

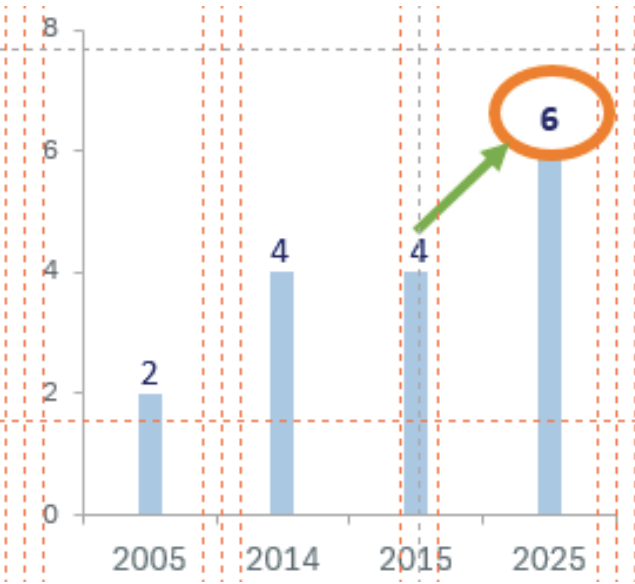

Source: The Wealth Report 2016 (Knight Frank) , p. 56.

\section{Gaining trust in Wealth Management in Serbia}

There is still a need for excessive work from the Republic of Serbia in order to improve conditions for private wealth management. Banks in Serbia ambitiously started working with private banking back in 2006. One of the banks founded a branch office that dealt with private banking. The decision of the other banks was that during the initial phase, they deal with providing private banking services at their offices. To accomplish the realization of this decision, certain specializations and education for employed had to be provided (Milenković, 2015).

The rapid growth of the economy and active of individuals worked in benefit of private banking, which was established much easier as it had already been done in countries that were out of the transition process. The clientele that decide on private banking services were located around Switzerland, Luxembourg, Austria, and rarely New York. It's evident that the clientele would remain in Serbia if the adequate services were made possible for them.

However, in the recent period, this service has had lesser significance in our country. The attitude of banks that compensation of high expenditure is not possible based on collaboration with a small number of clients is the evidence that profitability is not a characteristic of this activity (Smith, Walter, 2003). Based on the experience of the banks so far, current conditions are not the best for the investment of additional means with the goal to promote this service. Also, the interest of other banks in this activity in the finance market is not very high. 


\section{Conclusion}

The growth of gross social product in Serbia is expected to be around 4\% in 2018, which is more than in 2017. For the GSP rise are responsible for bigger investments, bigger expenditure, and significant export. Quicker economic growth was expected, based on the original assessment. As a consequence of the economic crisis, there were focus changes among the wealthiest people in the world, with now focus being on the stability of their profit, rather than the increase of the same. Given the low rate of economic growth and the businesses dependency on the income from peculiar markets in the countries in transition, the emphasis is greater on the personal security of the wealthy, as inequality is increasing.

The first phase in the work of wealth managers is the plan development, which enables maintaining and increasing of the client's wealth according to financial situation, goals and the level of risk a client is willing to take. Once he's established the plan, the manager starts to meet with clientele, and tailor their wishes to their possibilities, learns the client's needs and desires. Also, managers nurture their relationships constantly. Clients in this domain are rare in Serbia. Also, in our country, there is a mix up between private and classic banking. Additionally, there is also identifying between private and classic banking services, which are offered to important clientele, and yet it only acts as one trait of the process.

Wealth managers can be hired to work with small businesses, or in bigger firms that are connected with the finance industry. Financial consultant or financial advisor are other titles connected with wealth managers, which is inclined with the work they do. One designated wealth manager or the members of teams can provide the services of wealth management to clients.

\section{References}

Adam, T. (2009): Capital expenditures, financial constraints, and the use of options, Journal of Financial Economics 92, 238-251.

Ait-Sahalia, Y. and R. Kimmel (2007). Maximum Likelihood Estimation of Stochastic Volatility Models. Journal of Financial Economics 83 (2), 413-452.

Amenc, N., F. Goltz, and A. Lioui (2011): Practitioner Portfolio Construction and Performance Measurement: Evidence from Europe, Financial Analysts Journal 67(3), 39-50.

Amenc, N., F. Goltz, V. Le Sourd, and L. Martellini (2008): European Investment Practices Survey, EDHEC-Risk Publication.

Amenc, N., L. Martellini, and V. Ziemann (2007): Asset-Liability Management Decisions in Household Finance, EHDEC Working paper.

Amenc, N., L. Martellini, V. Milhau, and V. Ziemann (2009). Asset-liability management in private wealth management. Journal of Portfolio Management $36(1), 100-120$.

Amenc, N., S. Focardi, F. Goltz, D. Schröder, and L. Tang (2010). Edhec-risk european private wealth management survey. EDHEC-Risk Institute Publication. Available at http://www.edhec-risk. com/edhec publications/all publications/ RISKReview.2010-11-30.5229/attachments/EDHEC-Risk European Private Wealth Management Survey.pdf. 
Ang, S-K. 2010. A Qualitative Study on the Challenges of Private Banking in Asia. The Journal of Wealth Management, 12, (4): pp. 68-77.

Bajeux-Besnainou, I., J. Jordan, and R. Portait (2003). Dynamic Asset Allocation for Stocks, Bonds, and Cash. The Journal of Business 76 (2), 263-287.

Balduzzi, P. and A. W. Lynch (1999): Transaction costs and predictability: Some utility cost calculations, Journal of Financial Economics 52(1): 47-78.

Basu, A. and A. Brisbane (2009). Towards a dynamic asset allocation framework for target retirement funds: Getting rid of the dogma in lifecycle investing. Working Paper.

Basu, A. and M. Drew (2009). Portfolio size effect in retirement accounts: What does it imply for lifecycle asset allocation funds? The Journal of Portfolio Management 35 (3), 61-72.

Beaverstock, J. V., Hall, S., Wainwright, T. 2013. Servicing the Super-Rich: New Financial Elites and the Rise of the Private Wealth Management Retail Ecology. Regional Studies, 47, (6): 834-849.

Benzoni, L., P. Collin-Dufresne, and R. Goldstein (2007). Portfolio choice over the life-cycle when the stock and labor markets are cointegrated. Journal of Finance 62 (5), 2123-2167.

Black, F. and A.R. Perold (1992): Theory of constant proportion portfolio insurance, Journal of Economic Dynamics and Control 16, 403-426.

Black, F. and R. Litterman (1992): Global Portfolio Optimization, Financial Analysts Journal 48(5), 28- 43.

Blake and K. Dowd (2006): Stochastic lifestyling: Optimal dynamic asset allocation for defined contribution pension plans, Journal of Economic Dynamics and Control 30(5), 843-877.

Bodie, Z., J. Detemple, and M. Rindisbacher (2009). Life cycle finance and the design of pension plans. 1, 249-286. Annual Review of Financial Economics.

Bodie, Z., R. C. Merton, and W. Samuelson (1992): Labor Supply Flexibility and Portfolio Choice in a Life-Cycle Model, Journal of Economic Dynamics and Control 16, 427-449.

Brau, J. and S. Fawcett (2006): Initial Public Offerings: An analysis of theory and practice, Journal of Finance 61(1), 399-436.

Brav, A., J.R. Graham, C.R. Harvey, and R. Michaely (2005): Payout policy in the 21 st century, Journal of Financial Economics 77(3), 483-527.

Brennan, M. and Y. Xia (2002). Dynamic asset allocation under inflation. Journal of Finance 57 (3), 1201-1238.

Brennan, M., E. Schwartz, and R. Lagnado (1997). Strategic asset allocation. Journal of Economic Dynamics and Control 21 (8-9), 1377-1403.

Brounen, D., de Jong, A., and K. Koedjik (2006): Capital structure policies in Europe: survey evidence, Journal of Banking \& Finance 30(5), 1409-1442.

Brunel, J. L.P. (2006a): Integrated Wealth Management: The New Direction for Portfolio Managers, 2nd ed. London: Euromoney Books.

Brunel, J. L.P. (2006b): How Sub-Optimal-If at All-Is Goal-Based Asset Allocation? Journal of Wealth Management 9(2), 19-34. Cairns, A. J. G, D.

Cairns, A., D. Blake, and K. Dowd (2006). Stochastic lifestyling: Optimal dynamic asset allocation for defined contribution pension plans. Journal of Economic Dynamics and Control 30 (5), 843-877. 
Campbell, J. and L. Viceira (1999). Consumption and portfolio decisions when expected returns are time varying. Quarterly Journal of Economics 114 (2), 433-495.

Campbell, J. and L. Viceira (2005). The term structure of the risk-return trade-off. Financial Analysts Journal 61 (1), 34-44.

Campbell, J., Y. Chan, and L. Viceira (2003). A multivariate model of strategic asset allocation. Journal of Financial Economics 67 (1), 41-80.

Chacko, G. and L. Viceira (2005). Dynamic consumption and portfolio choice with stochastic volatility in incomplete markets. Review of Financial Studies 18 (4), 1369-1402.

Cocco, J., F. Gomes, and P. Maenhout (2005). Consumption and portfolio choice over the life cycle. Review of Financial Studies 18 (2), 491-533.

Cvitanic, J. and I. Karatzas (1995). On portfolio optimization under "drawdown" constraints. IMA Volumes in Mathematics and Its Applications 65, 35-35.

Deguest, R., L. Martellini, and V. Milhau (2011). Hedging versus insurance: Longhorizon investing with short-term constraints. Working Paper. EDHEC-Risk Institute.

Detemple, J. and M. Rindisbacher(2010). Dynamic asset allocation: Portfolio decomposition formula and applications. Review of Financial Studies 23 (1), 25-100.

Detemple, J., R. Garcia, and M. Rindisbacher (2003). A Monte Carlo method for optimal portfolios. Journal of Finance 58 (1), 401-446.

Groh, A. P., von Liechtenstein, H., \& Lieser, K. (2010). The European Venture Capital and Private Equity country attractiveness indices. Journal of Corporate Finance, 16(2), 205-224.

https://worldwealthreport.com/resources/world-wealth-report-2018/: 12.03.2019.

https://www.addiko.rs: 19.03.2019.

https://www.ey.com/Publication/vwLUAssets/ey-wealth-management-outlook2018/\$file/ey-wealth-management-

https://www.investopedia.com/terms/w/wealthmanagement.asp: 01.03.2019.

https://www.knightfrank.com: 18.03.2019.

https://www.unicreditbank.rs: 19.03.2019.

Invest Europe. (2016). Central and Eastern European Private Equity Statistics 2015. Retrieved from https: //www.

Invest Europe. (2016). Central and Eastern European Private Equity Statistics 2015.

Investeurope. Eu/media/504370/invest-europe-cee-statistics-2015. pdf.

Jääskeläinen, M., Maula, M., \& Murray, G. (2007). Profit distribution and compensation structures in publicly and privately funded hybrid venture capital funds. Research Policy, 36(7),

Jennings, W. W., Horan, S. M., Reichenstein, W., Brunel, J. L. P. (2011). Perspectives From The Literature Of Private Wealth Management. The Journal of Wealth Management, 14, (1): p8-40.

Ljumović, I., Marinković, S. (2013). What Makes Bank Go Global in National and European Identity in The Process of European Integration, International Thematic Proceedings. Belgrade: Institute of International Politics and Economics: 473488. 
Milenković, N. (2015). Rizični i privatni kapital u zemljama Centralne i Istočne Evrope. Novi Sad: Univerzitet u Novom Sadu, Ekonomski fakultet u Subotici (Doktorska disertacija).

outlook-2018.pdf: 11.03.2019.

Pistor, K., Martin, R., Gelfer, S., (2004), Law and Finance in Transition Economies, European Bank for Reconstruction and Development, Working paper No. 49, 171-213.

Schoefer, P., \& Leitinger, R. (2002). Framework for Venture Capital in the Accession Countries to the European Union. Viena Univeristy of Applied Sciences working paper.

Smith. R., Walter, I. (2003). Global banking, second edition. Oxford: Oxford University Press.

The Wealth Report 2016 (Knight Frank), https://content.knightfrank.com/research/83/ documents/en/wealth-report-2016-3579.pdf 